\title{
Intravenous Ketamine Infusions in Treatment-Resistant Bipolar Depression: An Open-Label Naturalistic Observational Study
}

\author{
Alina Wilkowska (D) \\ Adam Włodarczyk (D) \\ Maria Gałuszko- \\ Węgielnik \\ Mariusz S Wiglusz \\ Wiesław J Cubała (ID)
}

Department of Psychiatry, Faculty of Medicine, Medical University of Gdańsk, Gdańsk, Poland
Correspondence: Alina Wilkowska Department of Psychiatry, Faculty of Medicine, Medical University of Gdańsk, Gdańsk, Poland

Tel + 48583492650

$\mathrm{Fax}+483492748$

Email ali.wilkowska@gmail.com
Purpose: Bipolar disorder is a chronic and recurrent condition often associated with treatment resistance and suicidality. There is an unmet need for effective treatment in this group of patients. Ketamine has been demonstrated to have antidepressant and antisuicidal properties in unipolar depression. Most of the available studies concern unipolar depression. Here, we present the efficacy and safety of IV ketamine as an add-on treatment in patients with bipolar I and bipolar II depression.

Patients and Methods: Thirteen patients with treatment-resistant bipolar depression (TRBD) received eight IV infusions of $0.5 \mathrm{mg} / \mathrm{kg}$ ketamine twice a week over four weeks. This is an open-label naturalistic observational study. Ketamine is an add-on treatment. Depressive symptoms were measured with the Montgomery-Asberg Depression Rating Scale (MADRS), and manic symptoms were measured with the Young Mania Rating Scale (YMRS). Psychomimetic symptoms were assessed with the Clinician-Administered Dissociative States Scale (CADSS) and the Brief Psychiatric Rating Scale (BPRS).

Results: The rates of response and remission after the seventh infusion of ketamine were $61.5 \%$ and $46.2 \%$, respectively. A significant antisuicidal effect was observed in responders at the 7 th infusion. Suicidality was measured with item 10 on the MADRS scale. The average time to respond was between 21.1 and 23.2 days to remission. There was an increase in the CADSS scores during the treatment compared to baseline and follow-up, but no differences between responders and non-responders were observed. No affective switch was observed according to the YMRS scale scores. Ketamine treatment was associated with a transient increase in arterial blood pressure. No serious adverse events, however, were observed.

Conclusion: This report presents the preliminary results of IV ketamine effectiveness and safety in treatment-resistant bipolar depression. The findings suggest that it is a feasible, safe and well-tolerated treatment option in this group of patients. There is a definite need for more studies in this field.

Keywords: bipolar depression, intravenous ketamine, safety, tolerability, treatment-resistant bipolar disorder

\section{Introduction}

Bipolar disorder (BD) is a debilitating and recurrent psychiatric condition affecting more than $1 \%$ of the population. The risk of suicide in this group of patients is high. ${ }^{1,2}$ Bipolar depression is often treatment resistant. ${ }^{3-5}$ To our knowledge, there are currently 140 trials of ketamine conducted in psychiatric disorders. Most of them include MDD patients, only $0.7 \%$ include specifically bipolar patients, and 
$5.7 \%$ include both. ${ }^{6}$ Ketamine in BD is clearly understudied, although its rapid antidepressant and antisuicidal effect in MDD suggests that it could be useful in bipolar patients. $^{7-11}$ A few studies have investigated the effect of a single infusion of ketamine as an add-on treatment in $\mathrm{BD}$, with the response rate at around 50\%. ${ }^{9-15}$ Studies involving the multiple administration of ketamine in bipolar patients, however, are scarce. ${ }^{16-19}$ Treatment resistance in bipolar disorder is common, although the exact prevalence is hard to assess. ${ }^{20}$ Data on pharmacotherapeutic strategies in this group of patients are still insufficient. There are also little data on the efficacy, safety and tolerability of ketamine in the TRBD population. ${ }^{9,10}$

This report presents the effect of repeated IV ketamine infusions on mood and suicidality in TRBD I and II patients with monitoring of manic, dissociative and psychomimetic symptoms along with somatic safety measures. The study was conducted in a real-world setting and included patients who were treated with multiple psychotropic medications.

\section{Materials and Methods}

\section{Patients}

The study population includes subjects enrolled in a naturalistic observational registry protocol for IV ketamine treatment in TRD (NCT04226963). The methodology is described in detail elsewhere. ${ }^{21}$ The present study comprises a population of thirteen patients with depressive episodes without psychotic features in the course of bipolar disorder. Patients were diagnosed according to the Diagnostic and Statistical Manual of Mental Disorders (DSM-5). All participants exhibited treatment resistance for the current episode, defined as a clinically unsatisfactory response to two approved and adequate interventions for bipolar depression. ${ }^{22}$

The study was carried out in accordance with the latest version of the Declaration of Helsinki. ${ }^{23}$ For each participant, written informed consent was obtained after the procedures had been fully explained. The study protocol was approved by the Ethic Research Committee of the Medical University of Gdańsk (NKBBN/172/2017; 172 674/2019).

\section{Study Design}

Eight IV ketamine infusions were administered over 4 weeks as an add-on treatment. The ketamine dose was $0.5 \mathrm{mg} / \mathrm{kg}$ infused over $40 \mathrm{~min}$. Safety monitoring included the assessment of vital signs, BPRS and CADSS at baseline and 1 hour after the infusion.

The primary outcomes were the response and remission rates. Response was defined as a $50 \%$ or higher reduction in MADRS from the baseline. The criterion of remission was 10 or less points in MADRS. ${ }^{24}$ The groups (remitters, responders, non-remitters) were determined at the 7 th infusion. Secondary outcomes were suicidal thoughts measured by item 10 in MADRS, time to response and remission, manic symptoms measured by YMRS, psychotic symptoms and dissociative symptoms measured by CADSS and BPRS.

\section{Statistical Analyses}

The data were analyzed with the IBM SPSS Statistics package ver 25 . The normality of the continuous variables was examined by the Shapiro-Wilk test. The demographic and clinical characteristics of responder and non-responder groups (defined using the MADRS score after seventh infusion) were compared using Fisher's exact test for categorical variables and an independent sample $t$-test or the Mann-Whitney $U$-test for continuous variables (an appropriate effect size for each test was provided). Kaplan-Meier survival analysis was applied to analyze the average time to response and remission. Comparisons of the MADRS total score (as this variable met the criteria for applying the parametric test) were analyzed using the ANOVA mixed model with Tukey's post hoc test. MADRS item no. 10, YMRS, BPRS and CADSS were analyzed first using Friedman's ANOVA (with Dunn's post hoc test) to assess the score change during the subsequent infusions in two groups. Next, the differences between the responders and non-responders at each assessment time point were examined using Mann-Whitney $U$-tests with correction for multiple comparisons. All the statistical tests were two-tailed and were considered to be significant at $\mathrm{p}<0.05$.

\section{Results}

\section{Demographics and Concomitant} Treatment

There were no significant differences in any demographic or clinical characteristics between the responder and nonresponder groups. Data are presented in Table 1.

Ketamine is an add-on treatment. The concomitant psychotropic medications for every included patient are presented in Table 2. 
Table I Demographic and Clinical Characteristics in the Responder and the Non-Responder Group

\begin{tabular}{|c|c|c|c|c|}
\hline Variables & Total Sample $(\mathbf{N}=13)$ & Responders $(n=8)$ & Non-Responders $(n=5)$ & Difference; Effect Size \\
\hline Age & $49.5(15.1)$ & $51.3(11.5)$ & $46.6(20.9)$ & $t=0.52 ; d=0.30$ \\
\hline BMI & $29.0(6.3)$ & $28.6(7.0)$ & $29.6(5.6)$ & $t=-0.26 ; d=0.15$ \\
\hline Depression duration (weeks) & $24.0(16-36)$ & $18.5(|4-3|)$ & $26.0(24-96)$ & $Z=-0.74 ; \eta^{2}=0.04$ \\
\hline \multicolumn{5}{|l|}{ Number of episodes } \\
\hline Depressive & $7.6(4.0)$ & $9.0(4.3)$ & $5.4(2.3)$ & $t=-1.70 ; d=0.97$ \\
\hline Manic & $2.0(2.0)$ & $2.5(2.3)$ & $1.2(0.8)$ & $t=-1.18 ; d=0.68$ \\
\hline Hypomanic & I.0 (0.8) & I.3 (0.7) & $0.8(0.8)$ & $t=-1.04 ; d=0.59$ \\
\hline Mixed & $0(0-0)$ & $0(0-0)$ & $0(0-0)$ & $Z=0.07 ; \eta^{2}<0.01$ \\
\hline \multicolumn{5}{|c|}{ Baseline results (before infusion) } \\
\hline MADRS & $30.1(9.0)$ & $30.1(10.3)$ & $30.0(7.7)$ & $t=0.02 ; d=0.01$ \\
\hline MADRS item no. 10 & $2.0(I-4)$ & $3.0(0.5-5)$ & $1.0(I-2)$ & $Z=0.82 ; \eta^{2}=0.05$ \\
\hline YMRS & $3.0(I-4)$ & $3.5(2-6)$ & $2.0(0-3)$ & $Z=1.33 ; \eta^{2}=0.14$ \\
\hline BPRS & $0(0-0)$ & $0(0-1.5)$ & $0(0-0)$ & $Z=0.00 ; \eta^{2}<0.01$ \\
\hline CADSS & $0(0-0)$ & $0(0-0)$ & $0(0-0)$ & $Z=0.63 ; \eta^{2}=0.03$ \\
\hline \multicolumn{5}{|l|}{ Sex } \\
\hline Females & $10(76.9 \%)$ & $5(62.5 \%)$ & $5(100 \%)$ & Fisher $=n s ; \varphi=0.43$ \\
\hline Males & $3(23.1 \%)$ & $3(37.5 \%)$ & $0(0 \%)$ & \\
\hline Secondary & 7 (7.7\%) & $5(62.5 \%)$ & $2(40.0 \%)$ & Fisher $=1.84 ; \mathrm{V}=0.38$ \\
\hline Vocational & I (53.8\%) & $\mathrm{I}(12.5 \%)$ & $0(0 \%)$ & \\
\hline Higher & $5(38.5 \%)$ & $2(25.0 \%)$ & $3(60.0 \%)$ & \\
\hline \multicolumn{5}{|l|}{ Employment status } \\
\hline Employed & $2(15.4 \%)$ & $2(25.0 \%)$ & $0(0 \%)$ & Fisher $=1.53 ; \mathrm{V}=0.37$ \\
\hline Unemployed & $8(61.5 \%)$ & $4(50.0 \%)$ & $4(80.0 \%)$ & \\
\hline Pension & $3(23.1 \%)$ & $2(25.0 \%)$ & I (20.0\%) & \\
\hline \multicolumn{5}{|l|}{ Bipolar subtype } \\
\hline I & $10(76.9 \%)$ & $6(75.0 \%)$ & $4(80.0 \%)$ & Fisher=ns; $\varphi=0.06$ \\
\hline II & $3(23.1 \%)$ & $2(25.0 \%)$ & I (20.0\%) & \\
\hline \multicolumn{5}{|l|}{ Comorbidities } \\
\hline Epilepsy & $4(30.8 \%)$ & $3(37.5 \%)$ & I (20.0\%) & Fisher=ns; $\varphi=0.18$ \\
\hline Hypertension & $5(38.5 \%)$ & $4(50.0 \%)$ & I (20.0\%) & Fisher $=n s ; \varphi=0.30$ \\
\hline Diabetes & $2(15.4 \%)$ & $2(25.0 \%)$ & $0(0 \%)$ & Fisher=ns; $\varphi=0.34$ \\
\hline Hypercholesterolemia & $2(15.4 \%)$ & $2(25.0 \%)$ & $0(0 \%)$ & Fisher=ns; $\varphi=0.34$ \\
\hline Other & 5 (38.5\%) & $4(50.0 \%)$ & I (20.0\%) & Fisher=ns; $\varphi=0.30$ \\
\hline \multicolumn{5}{|l|}{ Co-existing treatment } \\
\hline Mood stabilizers & $10(76.9 \%)$ & 7 (87.5\%) & $3(60.0 \%)$ & Fisher $=n s ; \varphi=0.32$ \\
\hline $2^{\text {nd }}$ generation antipsychotics & $9(69.2 \%)$ & $6(75.0 \%)$ & $3(60.0 \%)$ & Fisher=ns; $\varphi=0.16$ \\
\hline Antidepressants & 9 (69.2\%) & $5(62.5 \%)$ & $4(80.0 \%)$ & Fisher $=\mathrm{ns} ; \varphi=-0.18$ \\
\hline
\end{tabular}

Notes: For the $t$-test, the mean and standard deviations are given; in the case of the $U$-test, the median and $25 \%-75 \%$ quartiles are given; for Fisher's Exact Test, the number of patients and percentage are given. $t-t$ statistics (Student's $t$-test for independent samples), $d$ - Cohen's $d$ (effect size for $t$-test), $Z-Z$ statistics (Mann-Whitney $U$-test for independent samples), $\eta 2$ - eta-square (effect size for $U$-test), Fisher - Fisher's Exact Test, ns - not significant; $\varphi$ - phi or $V$ - Cramer's $V$ (effect size for contingency tables). Abbreviations: BMI, Body Mass Index; MADRS, Montgomery-Asberg Depression Rating Scale Young; YMRS, Mania Rating Scale; CADSS, Clinician-Administered Dissociative States Scale; BPRS, Brief Psychiatric Rating Scale. 
Table 2 Coexisting Psychotropic Treatment

\begin{tabular}{|c|c|c|c|c|c|c|c|}
\hline \multirow{2}{*}{$\begin{array}{l}\text { Patient } \\
\text { No. } \\
\text { I }\end{array}$} & \multicolumn{3}{|l|}{ Mood Stabilizers } & \multicolumn{2}{|c|}{ Antipsychotics } & \multirow{2}{*}{ Antidepressants } & \multirow[t]{2}{*}{ Benzodiazepines } \\
\hline & $\begin{array}{l}\text { Valproic acid } \\
2000 \mathrm{mg} / \mathrm{d}\end{array}$ & & & $\begin{array}{l}\text { Quetiapine } \\
500 \mathrm{mg} / \mathrm{d}\end{array}$ & $\begin{array}{l}\text { Venlafaxine } \\
150 \mathrm{mg} / \mathrm{d}\end{array}$ & & \\
\hline 2 & $\begin{array}{l}\text { Valproic acid } \\
2000 \mathrm{mg} / \mathrm{d}\end{array}$ & & & $\begin{array}{l}\text { Quetiapine } \\
400 \mathrm{mg} / \mathrm{d}\end{array}$ & $\begin{array}{l}\text { Duloxetine } \\
120 \mathrm{mg} / \mathrm{d}\end{array}$ & & \\
\hline 3 & Lithium $750 \mathrm{mg} / \mathrm{d}$ & & & & $\begin{array}{l}\text { Venlafaxine } \\
225 \mathrm{mg} / \mathrm{d}\end{array}$ & $\begin{array}{l}\text { Mirtazapine } 45 \mathrm{mg} / \\
\mathrm{d}\end{array}$ & \\
\hline 4 & Lithium $1000 \mathrm{mg} / \mathrm{d}$ & & & $\begin{array}{l}\text { Aripiprazole } \\
15 \mathrm{mg} / \mathrm{d}\end{array}$ & & & \\
\hline 5 & Lithium $1000 \mathrm{mg}$ & $\begin{array}{l}\text { Lamotrigine } \\
200 \mathrm{mg} / \mathrm{d}\end{array}$ & $\begin{array}{l}\text { Valproic acid } \\
\text { I300/d }\end{array}$ & & & & Lorazepam $2.5 \mathrm{mg}$ \\
\hline 6 & $\begin{array}{l}\text { Lamotrygine } 100 \mathrm{mg} / \\
\text { d }\end{array}$ & $\begin{array}{l}\text { Pregabaline } \\
300 \mathrm{mg} / \mathrm{d}\end{array}$ & & $\begin{array}{l}\text { Olanzapine } \\
5 \mathrm{mg} / \mathrm{d}\end{array}$ & $\begin{array}{l}\text { Bupropione } \\
300 \mathrm{mg} / \mathrm{d}\end{array}$ & $\begin{array}{l}\text { Mirtazapine } 30 \mathrm{mg} / \\
\mathrm{d}\end{array}$ & Lorazepam $2 \mathrm{mg} / \mathrm{d}$ \\
\hline 7 & & & & $\begin{array}{l}\text { Quetiapine } \\
600 \mathrm{mg}\end{array}$ & $\begin{array}{l}\text { Citalopram } \\
30 \mathrm{mg}\end{array}$ & & Lorazepam 3mg \\
\hline 8 & $\begin{array}{l}\text { Valproic acid } \\
1200 \mathrm{mg} / \mathrm{d}\end{array}$ & $\begin{array}{l}\text { Lamotrigine } \\
200 \mathrm{mg} / \mathrm{d}\end{array}$ & & & & & \\
\hline 9 & $\begin{array}{l}\text { Valproic acid } \\
3000 \mathrm{mg} / \mathrm{d}\end{array}$ & & & & & & \\
\hline 10 & $\begin{array}{l}\text { Valproic acid } \\
2000 \mathrm{mg} / \mathrm{d}\end{array}$ & $\begin{array}{l}\text { Lamotrigine } \\
200 \mathrm{mg} / \mathrm{d}\end{array}$ & & $\begin{array}{l}\text { Risoeridone } \\
5 \mathrm{mg} / \mathrm{d}\end{array}$ & $\begin{array}{l}\text { Fluoxetine } \\
30 \mathrm{mg} / \mathrm{d}\end{array}$ & & \\
\hline II & Valproic acid I500/d & $\begin{array}{l}\text { Lamotrigine } \\
200 \mathrm{mg} / \mathrm{d}\end{array}$ & & & $\begin{array}{l}\text { Venlafaxine } \\
300 \mathrm{mg} / \mathrm{d}\end{array}$ & & \\
\hline 12 & $\begin{array}{l}\text { Lithium carbonicum } \\
1250 \mathrm{mg} / \mathrm{d}\end{array}$ & $\begin{array}{l}\text { Lamotrigine } \\
100 \mathrm{mg} / \mathrm{d}\end{array}$ & & $\begin{array}{l}\text { Quetiapine } \\
50 \mathrm{mg} / \mathrm{d}\end{array}$ & & & \\
\hline 13 & Lithium $1000 \mathrm{mg} / \mathrm{d}$ & & & $\begin{array}{l}\text { Olanzapine } \\
20 \mathrm{mg} / \mathrm{d}\end{array}$ & $\begin{array}{l}\text { Fluoxetine } \\
40 \mathrm{mg} / \mathrm{d}\end{array}$ & & Lorazepam Img \\
\hline
\end{tabular}

\section{Antidepressant and Antisuicidal Effects}

The baseline average MADRS score was 30 . The average number of previous depressive episodes was 7.6, and the average duration of the current episode was 24 weeks. The results of the mixed ANOVA with the within-subjects factor and the between-subjects factor showed a significant interaction effect $-F(4.44)=3.78, p=$ $0.010, \eta 2 \mathrm{p}=0.26$.

We found that in the responder group, the MADRS score after the fifth infusion $(M=15.5)$ and the seventh infusion $(\mathrm{M}=8.3)$ was significantly lower compared to the baseline ( $\mathrm{M}=30.1$;

Tukey's post hoc test $\mathrm{p}=0.001$ and $\mathrm{p}<0.001$, respectively) which was not observed among non-responders.
Although, in the group of respondents, there was an increase in MADRS scores between the 21st day (after 7 infusion) and the final measurement (28th day of follow-up), it was not statistically significant. Moreover, the final score was still significantly lower $(M=15.9)$ than at the baseline (Tukey's post hoc test $p=0.002$ ). In the group of non-responders, the scores were still decreasing $(M=20.8)$ at the end of the study, but the decrease was not significant, neither compared to the results after the seventh infusion ( $\mathrm{M}=25.8)$ nor compared to the baseline results $(M=30.0)$ (Figure 1, Table 3).

Significant differences (Tukey's post hoc test) between the two groups in MADRS scores were found only after the seventh infusion $-\mathrm{M}=8.3$ (for responders) vs $\mathrm{M}=$ 25.8 (for non-responders), $\mathrm{p}=0.023$ (Figure 1, Table 3). 


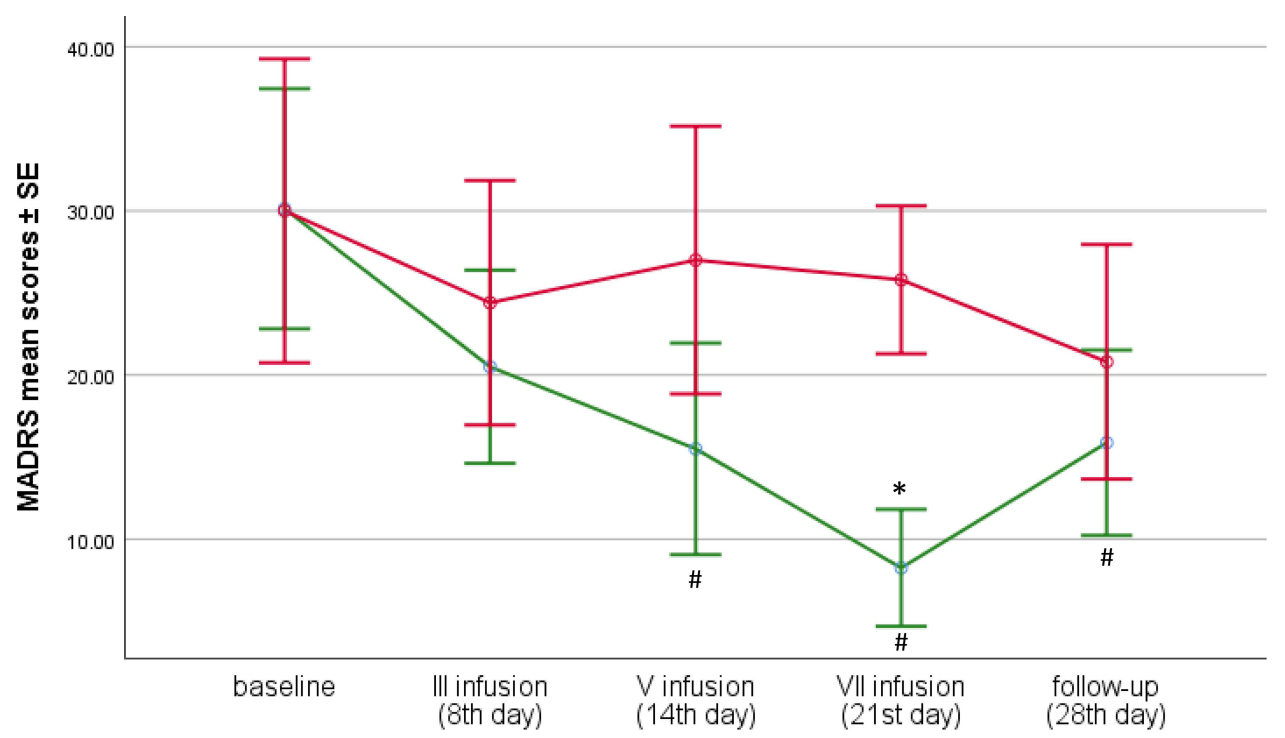

Figure I MADRS change after seven ketamine infusions in responders and non-responders. \# indicates significant difference at a given time point when compared to baseline * indicates significant difference at a given time point between the responder and non-responder groups $(p<0.05)$.

Partially similar conclusions were obtained when analyzing the results of the MADRS item no. 10. Due to the nature of the variable, non-parametric tests were used for the analysis. Friedman's ANOVA performed in the subgroups showed that there is a significant change of the severity of suicidal thoughts during subsequent infusions $-\chi^{2}(4)=13.87, p=$ $0.008, \mathrm{~W}=0.27$ among the responders, but not in the nonresponders group $-\chi^{2}(4)=5.35, p=0.256, W=0.10$. In this first group of patients, the distribution of scores obtained in MADRS item no. 10 after the seventh infusion was different and indicated a lower intensity of suicidal thoughts $(\mathrm{Me}=$ $0.00)$ than at the beginning of the study $(\mathrm{Me}=3.00)$ - Dunn's test $p=0.006$. The other results, however, did not differ from each other. There were also no differences between the groups. The results are presented in Table 4.

\section{Time to Response and Remission}

Figure 2 presents Kaplan-Meier curves for time to response [average time: 21.1 (95\% CI: 17.5 to 24.6); median time: 21.0 (95\% CI: 15.0 to 27.0$)$ days] and

Table 3 Mean Scores of MADRS at the Beginning and at the End of the Study, as Well as During Subsequent Infusions in the Total Sample and Separately Among Responders and Non-Responders (with Tukey's Post-Hoc Tests)

\begin{tabular}{|c|c|c|c|c|}
\hline Time Point & $\begin{array}{l}\text { Total Sample } \\
(\mathrm{N}=13)\end{array}$ & $\begin{array}{l}\text { Responders } \\
(n=8)\end{array}$ & $\begin{array}{l}\text { Non-Responders } \\
(n=5)\end{array}$ & $\begin{array}{l}\text { Between Group Difference - p-value; } \\
\text { Effect Size }\end{array}$ \\
\hline Baseline MADRS & $30.1(9.0)$ & $30.1(10.3)$ & $30.0(7.7)$ & $1.000 ; d=0.01$ \\
\hline $3^{\text {rd }}$ infusion ( $8^{\text {th }}$ day) MADRS & $22.0(7.5)$ & $20.5(7.7)$ & $24.4(7.3)$ & $0.998 ; d=0.52$ \\
\hline $\begin{array}{l}5^{\text {th }} \text { infusion }\left(14^{\text {th }} \text { day }\right) \\
\text { MADRS }\end{array}$ & $19.9(9.8)$ & $15.5(8.3)$ & $27.0(8.3)$ & $0.355 ; d=1.39$ \\
\hline $\begin{array}{l}7^{\text {th }} \text { infusion }\left(21^{\text {st }} \text { day }\right) \\
\text { MADRS }\end{array}$ & I $5.0(9.9)$ & $8.3(4.2)$ & $25.8(5.2)$ & $0.023 ; d=3.72$ \\
\hline Follow-up ( $28^{\text {th }}$ day) MADRS & $17.8(7.4)$ & $15.9(6.7)$ & $20.8(8.1)$ & $0.989 ; d=0.66$ \\
\hline
\end{tabular}

Notes: The results are presented as means and standard deviations; $d$ - Cohen's $d$; values in bold indicate statistically significant results. 
Table 4 Median Scores of MADRS Item No. 10 at the Beginning and at the End of the Study, as Well as During Subsequent Infusions in the Total Sample and Separately Among Responders and Non-Responders (with U-Tests)

\begin{tabular}{|l|l|l|l|l|}
\hline Time Point & $\begin{array}{l}\text { Total Sample } \\
(\mathbf{N}=1 \mathbf{3})\end{array}$ & $\begin{array}{l}\text { Responders } \\
(\mathbf{n = 8})\end{array}$ & $\begin{array}{l}\text { Non-Responders } \\
(\mathbf{n}=\mathbf{5})\end{array}$ & $\begin{array}{l}\text { Between Group Difference - p-value; } \\
\text { Effect Size }\end{array}$ \\
\hline Baseline MADRS item no. 10 & $2.0(1-4)$ & $3.0(0.5-5)$ & $1.0(I-2)$ & $0.412 ; \eta^{2}=0.05$ \\
\hline $\begin{array}{l}3^{\text {rd }} \text { infusion }\left(8^{\text {th }} \text { day) MADRS item }\right. \\
\text { no. } 10\end{array}$ & $1.0(0-3)$ & $0.5(0-2)$ & $1.0(0-3)$ & $0.815 ; \eta^{2}<0.01$ \\
\hline $\begin{array}{l}5^{\text {th }} \text { infusion }\left(14^{\text {th }} \text { day) MADRS }\right. \\
\text { item no. } 10\end{array}$ & $1.0(0-2)$ & $1.0(0-2)$ & $1.0(I-3)$ & $0.544 ; \eta^{2}=0.03$ \\
\hline $\begin{array}{l}7^{\text {th }} \text { infusion }\left(21^{\text {st }} \text { day) MADRS }\right. \\
\text { item no. } 10\end{array}$ & $0(0-1)$ & $0(0-0.5)$ & $0(0-2)$ & $0.528 ; \eta^{2}=0.03$ \\
\hline $\begin{array}{l}\text { Follow-up }\left(28^{\text {th }} \text { day) MADRS item }\right. \\
\text { no. } 10\end{array}$ & $1.0(0-2)$ & $1.0(0-2)$ & $2.0(0-2)$ & $0.820 ; \eta^{2}<0.01$ \\
\hline
\end{tabular}

remission [average time: 23.2 (95\% CI: 19.9 to 26.6$)$ ]; neither the median time nor $95 \%$ CI for median time was reached. The rates of response and remission (after the seventh infusion) were $61.5 \%$ and $46.2 \%$, respectively.

\section{Cardiovascular Safety}

Cardiovascular safety measures revealed a mild and temporary increase in the systolic and diastolic blood pressure, which returned to baseline values mostly within 1 hour after the beginning of the infusion. No significant changes were observed in body temperature, the breath count and blood saturation. We did not observe any serious adverse events associated with ketamine treatment and the most common side effects were dizziness, nausea, headache and insomnia. Dissociation was most commonly observed after the first and the second infusion and the intensity of symptoms decreased during subsequent infusions. BPRS scores mildly increased during the infusions and returned to normal after treatment. We observed a decrease in YMRS scores after the 5th infusion mainly due to

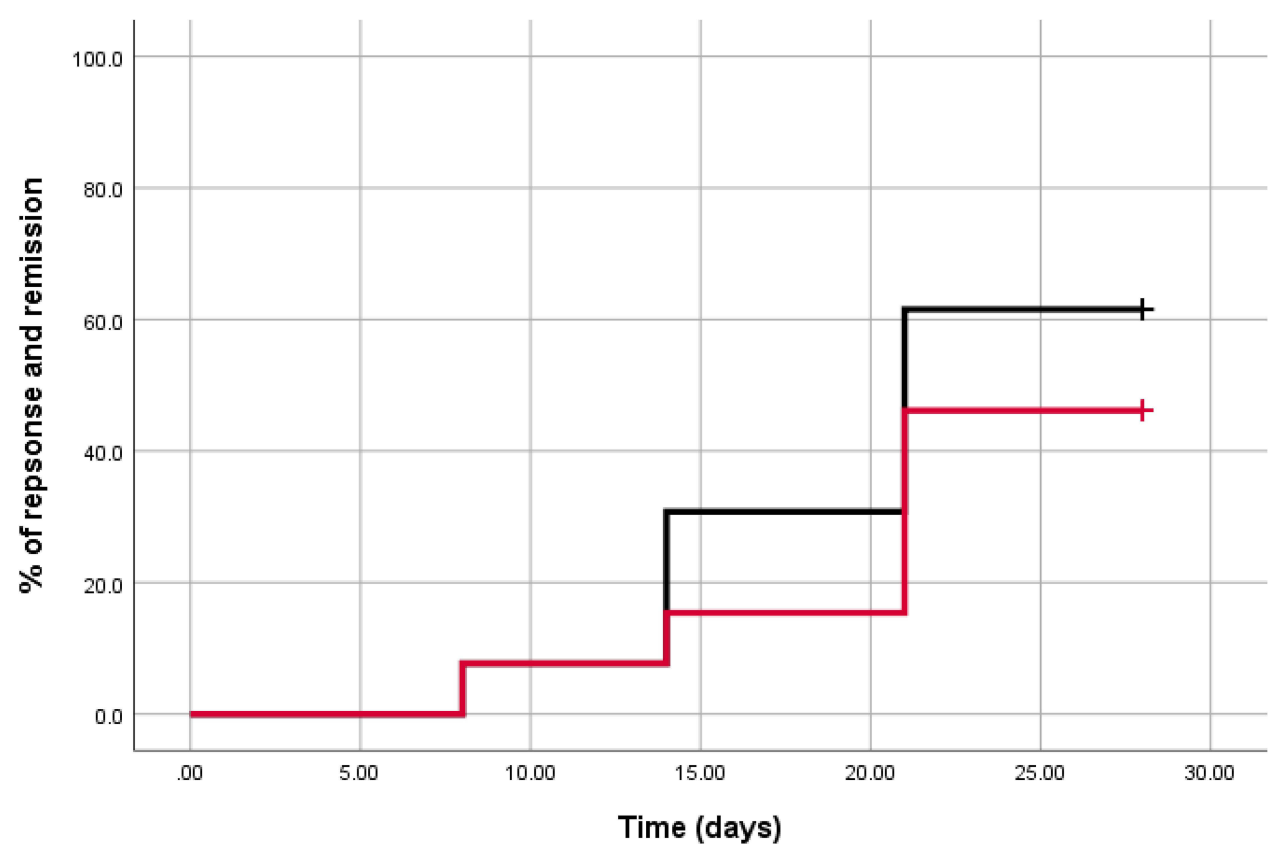

Figure 2 Kaplan-Meier curves for time to response and remission among bipolar patients. Black line indicates response, red line indicates remission. 
a decrease in irritability and sleep disturbances in the responders group. No patient exhibited psychosis, new onset of suicidality or an affective switch.

\section{Discussion}

The results of this study indicate safety, efficacy and a good tolerability profile of ketamine in bipolar I and bipolar II depression. This study replicates recent findings on the antidepressive and antisuicidal effect of repeated IV ketamine infusions in TRBD. The rates of response and remission (after the seventh infusion) were $61.5 \%$ and $46.2 \%$, respectively. Compared to Zheng ${ }^{18}(73,63 \%)$, the effect of ketamine in this study was not as good, but the population in our study was older (49.5 vs 35.8 ) and the average number of depressive episodes was 7.6. ${ }^{18}$ Most patients in Zheng's study had no history of psychiatric hospitalization although the number of previous episodes is not reported. According to studies, the history of previous hospitalizations is negatively associated with the response to ketamine. ${ }^{25,26}$ The number of prior episodes is also positively associated with lower response rates. ${ }^{26,27}$ There are also studies suggesting lower response rates in older patients, although the number of studies in this population is very scarce. ${ }^{28}$

Similarly to other studies, we observed an increase in response and remission rates with subsequent infusions. ${ }^{18,29}$ Nevertheless, the average time to response and remission were longer ( 21 and 23 days) compared to Zheng (9 and 12 days). ${ }^{18}$ It is possible that older patients with a severe course of bipolar disorder need more time to improve after ketamine treatment and possibly need more infusions. Ketamine improves neuroplasticity, synaptogenesis and BDNF levels. ${ }^{30,31}$ Studies have shown that low levels of BDNF are associated with an increased severity of bipolar episodes, ${ }^{32,33}$ and although the exact mechanism of the BDNF effect in bipolar disorder still needs to be elucidated, it is possible that these changes need more time to emerge in patients with a more severe course of the disease.

As in Zheng et $\mathrm{al}^{18}$ study, we also observed an increase in the MADRS score at follow-up (1 week after treatment). Although not statistically significant, this observation is in line with other reports. ${ }^{34,35}$ In line with other studies, we observed an antisuicidal effect reflected by a decrease in the score of item 10 in MADRS. This effect is described in a meta-analysis of single-infusion studies of MDD. ${ }^{36}$ Recent studies on repeated doses of IV ketamine in MDD and BP also confirmed its antisuicidal effect. ${ }^{17,18}$ A recent open-label clinical trial that administered six intravenous doses of $0.5 \mathrm{mg} / \mathrm{kg}$ ketamine three times a week in patients with unipolar and bipolar depression reported a significant reduction in suicidal ideation $-24 \mathrm{~h}$ after the first infusion in $57 \%$ of patients and in $65 \%$ after the sixth infusion. ${ }^{37}$ Some authors suggest that this effect is independent of the total depression symptom severity, ${ }^{38,39}$ but we did not observe this in our study.

Bipolar depression is a condition often requiring the use of a combinations of drugs. This should also be considered when analysing the ketamine response. Some evidence suggests that medications inducing cytochrome 450 CYP (2D6 and 3A4) may reduce the effect of ketamine and the inhibitors may increase the exposure to ketamine. Considering that most antipsychotics and antidepressants inhibit CYP 2D6, it can have a significant effect although this is unclear due to a lack of evidence. Genetic variations of CYP 2D6 may also influence the pharmacokinetics of ketamine. ${ }^{40}$ There are some data on the lower antidepressant effect of ketamine in combination with benzodiazepines. ${ }^{41,42}$ One study has shown that lamotrigine, which inhibits glutamatergic signalling, may reduce the side effects of ketamine, but it is not known if it also reduces the antidepressant effect. ${ }^{43}$

Particularly interesting in the context of bipolar disorder is the combination of ketamine and lithium. Both drugs share the mechanism of glycogen synthase kinase-3 (GSK-3) inhibition, which leads to the disinhibition of BDNF synthesis, long-term neuroplasticity and possibly mood stabilization. ${ }^{44}$ Ketamine and lithium activate the mechanistic target of rapamycin (mTOR) and BDNFtyrosine kinase receptor B (TrkB). As suggested by one animal study, lithium can maintain the restoration of spine density induced by a single injection of ketamine, and as a consequence, increase the antidepressant-like effects of ketamine in mice. ${ }^{45}$ In summary, there is an unquestionable need for more studies in this field, and the mentioned interactions are mostly speculative. Another significant matter concerns the possibility of developing adverse events in the course of ketamine/esketamine/arketamine treatment with coexisting medications like mood stabilizers, antipsychotics, benzodiazepines and somatic medications, which were reported in a post-marketing pharmacovigilance records analysis of intranasal esketamine. ${ }^{46}$ This can also be true for other enantiomers and the fact that we did not observe any significant side 
effects may be due to the small number of patients studied.

In correspondence with other studies, we did not observe any serious adverse events. Cardiovascular and psychomimetic side effects were mild, attenuated by subsequent infusions and did not cause treatment discontinuation. ${ }^{18,47-49}$ We also did not observe treatment for emergent psychiatric conditions like psychosis or mania. This observation confirms that ketamine treatment is safe in bipolar disorder patients with comorbidities.

Although the risk of an affective switch in available studies seems low, manic symptoms should be monitored in bipolar patients treated with ketamine, especially those treated with antidepressants. ${ }^{50}$ In this study, no affective switch was observed, although more studies on larger groups of bipolar patients are needed to confirm this observation.

\section{Limitations}

The main limitation is the small sample size. The openlabel design limits the interpretation of ketamine's effect. The observations apply to treatment-resistant patients with bipolar depression. It must be emphasized that the results apply to short-term treatment, and although the observation replicates published studies, further long-term trials are needed in order to demonstrate the efficacy of the intervention. The relatively short duration of the study may affect the response rates and tolerability measures. Ketamine serum concentrations were not evaluated. The efficacy, safety and tolerability profile cannot be generalized to real-world settings until RCTs with large sample sizes of bipolar patients are conducted. No standardized adverse reaction form was used.

\section{Conclusion}

Intravenous ketamine appears to be effective, safe and well tolerated in the short-term treatment of resistant patients with bipolar depression. Older patients with a severe course of the disease possibly need more time to respond. This is a preliminary study, and there is a need to conduct large, randomized, controlled trials of ketamine in bipolar disorder.

\section{Acknowledgments}

This paper was granted by the Medical University of Gdańsk, Poland (Grant No. ST-02-0039/07/221).

\section{Disclosure}

Dr Alina Wilkowska reports grants from Medical University of Gdańsk, during the conduct of the study and has received research support from Angelini, Biogen, Eli Lilly and Company, Janssen-Cilag, Lundbeck, Polpharma, Sanofi and Valeant. Dr Adam Włodarczyk has received research support from Actavis, Eli Lilly, Minerva Neurosciences, Sunovion Pharmaceuticals, KCR, Janssen, Otsuka, Apodemus, Cortexyme, and Acadia. Dr Maria Gałuszko-Węgielnik has received research support from Janssen, Servier, Alkermes, KCR, Lilly, Biogen, and Celon. Dr Mariusz S Wiglusz has received research support from Acadia, Apodemus, Alkermes, Auspex Pharmaceuticals, Cephalon, Ferrier, Forest Laboratories, Gedeon Richter, GWPharmaceuticals, Janssen, Lundbeck, Orion, Otsuka, Servier, Speakers Bureau: Lundbeck, Servier. Prof. Wiesław J Cubała has received research support from Acadia, Actavis, Alkermes, Allergan, Angelini, Auspex, Biogen, Bristol-Myers Squibb, Cephalon, Cortexyme, Eli Lilly, Ferrier, Forest Laboratories, Gedeon Richter, GW Pharmaceuticals, Janssen, KCR, Lundbeck, Minerva, NeuroCo, NIH, Orion, Otsuka, Sanofi, and Ser-vier; he has served on speakers bureaus for Adamed, Angelini, AstraZeneca, Bristol-Myers Squibb, Celon, GlaxoSmithKline, Janssen, Krka, Lekam, Lundbeck, Novartis, Orion, Pfizer, Polfa Tarchomin, Sanofi, Servier, and Zentiva; and he has served as a consultant for GW Pharmaceuticals, Janssen, KCR, Quintiles, and Roche. The authors report no other conflicts of interest in this work.

\section{References}

1. Abreu LN, Lafer B, Baca-Garcia E, Oquendo MA. Suicidal ideation and suicide attempts in bipolar disorder type I: an update for the clinician. Rev Bras Psiquiatr. 2009;2009(31):271-280. doi:10.1590/ s1516-44462009005000003

2. Jamison KR. Suicide and bipolar disorder. J Clin Psychiatry. 2000;61:47-51.

3. Li CT, Bai YM, Huang YL, et al. Association between antidepressant resistance in unipolar depression and subsequent bipolar disorder: cohort study. Br J Psychiatry. 2012;200:45-51. doi:10.1192/bjp. bp. 110.086983

4. Poon SH, Sim K, Sum MY, Kuswanto CN, Baldessarini RJ. Evidencebased options for treatment-resistant adult bipolar disorder patients. Bipolar Disord. 2012;14:573-584. doi:10.1111/j.13995618.2012.01042.x

5. Sienaert P, Lambrichts L, Dols A, De Fruyt J. Evidence-based treatment strategies for treatment-resistant bipolar depression: a systematic review. Bipolar Disord. 2013;15:61-69. doi:10.1111/bdi.12026

6. Peyrovian B, McIntyre RS, Phan L, et al. Registered clinical trials investigating ketamine for psychiatric disorders. $J$ Psychiatr Res. 2020;127:1-12. doi:10.1016/j.jpsychires.2020.03.020 
7. Berman RM, Cappiello A, Anand A, et al. Antidepressant effects of ketamine in depressed patients. Biol Psychiatry. 2000;47:351-354.

8. Zarate CA Jr, Singh J, Manji HK. Cellular plasticity cascades: targets for the development of novel therapeutics for bipolar disorder. Biol Psychiatry. 2006;59:1006-1020.

9. Diazgranados N, Ibrahim L, Brutsche NE, et al. A randomized add-on trial of an N-methyl-D-aspartate antagonist in treatment-resistant bipolar depression. Arch Gen Psychiatry. 2010;67:793-802. doi:10.1001/archgenpsychiatry.2010.90

10. Zarate CA Jr, Brutsche NE, Ibrahim L, et al. Replication of ketamine's antidepressant efficacy in bipolar depression: a randomized controlled add-on trial. Biol Psychiatry. 2012;1(71):939-946. doi:10.1016/j.biopsych.2011.12.010

11. Grunebaum MF, Ellis SP, Keilp JG, et al. Ketamine versus midazolam in bipolar depression with suicidal thoughts: a pilot midazolam-controlled randomized clinical trial. Bipolar Disord. 2017;19:176-183. doi:10.1111/bdi.12487

12. Ionescu DF, Luckenbaugh DA, Niciu MJ, Richards EM, Zarate CA Jr. A single infusion of ketamine improves depression scores in patients with anxious bipolar depression. Bipolar Disord. 2015;17:438-443.

13. Permoda-Osip A, Skibinska M, Bartkowska-Sniatkowska A, Kliwicki S, Chlopocka-Wozniak M, Rybakowski JK. Factors connected with efficacy of single ketamine infusion in bipolar depression. Psychiatr Pol. 2014;48:35-47.

14. Rybakowski JK, Permoda-Osip A, Bartkowska-Sniatkowska A. Ketamine augmentation rapidly improves depression scores in inpatients with treatment-resistant bipolar depression. Int J Psychiatry Clin Pract. 2017;21:99-103. doi:10.1080/13651501.2017.1297834

15. Correia-Melo FS, Argolo FC, Araújo-de-freitas L, et al. Rapid infusion of esketamine for unipolar and bipolar depression: a retrospective chart review. Neuropsychiatr Dis Treat. 2017;21 (13):1627-1632. doi:10.2147/NDT.S135623

16. Lara DR, Bisol LW, Munari LR. Antidepressant, mood stabilizing and procognitive effects of very low dose sublingual ketamine in refractory unipolar and bipolar depression. Int J Neuropsychopharmacol. 2013;16:2111-2117. doi:10.1017/ S1461145713000485

17. Zheng W, Zhou YL, Liu WJ, et al. Rapid and longer-term antidepressant effects of repeated-dose intravenous ketamine for patients with unipolar and bipolar depression. $J$ Psychiatr Res. 2018;106:61-68. doi:10.1016/j.jpsychires.2018.09.013

18. Zheng W, Zhou YL, Liu WJ, et al. A preliminary study of adjunctive ketamine for treatment-resistant bipolar depression. $J$ Affect Disord. 2020;275:38-43. doi:10.1016/j.jad.2020.06.020

19. McIntyre RS, Rodrigues NB, Lee Y, et al. The effectiveness of repeated intravenous ketamine on depressive symptoms, suicidal ideation and functional disability in adults with major depressive disorder and bipolar disorder: results from the Canadian Rapid Treatment Center of Excellence. $J$ Affect Disord. 2020;1 (274):903-910. doi:10.1016/j.jad.2020.05.088

20. Fornaro M, Carvalho AF, Fusco A, et al. The concept and management of acute episodes of treatment-resistant bipolar disorder: a systematic review and exploratory meta-analysis of randomized controlled trials. J Affect Disord. 2020;276:970-983. doi:10.1016/j. jad.2020.07.109

21. Słupski J, Cubała WJ, Górska N, Gałuszko-Węgielnik M. Copper and anti-anhedonic effect of ketamine in treatment-resistant depression. Med Hypotheses. 2020;144:110268. doi:10.1016/j.mehy.2020.110268

22. Poon SH, Sim K, Baldessarini RJ. Pharmacological approaches for treatment-resistant bipolar disorder. Curr Neuropharmacol. 2015;13 (5):592-604. doi:10.2174/1570159x13666150630171954

23. World Medical Association. World Medical Association Declaration of Helsinki ethical principles for medical research involving human subjects. JAMA. 2013;310(20):2191-2194. doi:10.1001/ jama.2013.281053
24. Trivedi MH, Corey-Lisle PK, Guo Z, et al. Remission, response without remission, and nonresponse in major depressive disorder: impact on functioning. Int Clin Psychopharmacol. 2009;24:133-138. doi:10.1097/YIC.0b013e3283277614

25. De CV, Calati R, Serretti A. Socio-demographic and clinical predictors of non-response/non-remission in treatment resistant depressed patients: a systematic review. Psychiatry Res. 2016;240:421-430.

26. Riedel M, Moller HJ, Obermeier M, et al. Clinical predictors of response and remission in inpatients with depressive syndromes. J Affect Disord. 2011;133:137-149. doi:10.1016/j.jad.2011.04.007

27. Gorwood P, Rouillon F, Even C, Falissard B, Corruble E, Moran P. Treatment response in major depression: effects of personality dysfunction and prior depression. Br J Psychiatry. 2010;196(2):139-142. doi:10.1192/bjp.bp.109.067058

28. Szymkowicz SM, Finnegan N, Dale RM. Failed response to repeat intravenous ketamine infusions in geriatric patients with major depressive disorder. J Clin Psychopharmacol. 2014;34:285-286.

29. Shiroma PR, Johns B, Kuskowski M, et al. Augmentation of response and remission to serial intravenous subanesthetic ketamine in treatment resistant depression. J Affect Disord. 2014;155:123-129. doi:10.1016/j.jad.2013.10.036

30. Dong C, Zhang JC, Yao W, et al. Rapid and sustained antidepressant action of the mGlu2/3 receptor antagonist MGS0039 in the social defeat stress model: comparison with ketamine. Int $J$ Neuropsychopharmacol. 2017;20:228-236. doi:10.1093/ijnp/pyw089

31. Moda-Sava RN, Murdock MH, Parekh PK, et al. Sustained rescue of prefrontal circuit dysfunction by antidepressant-induced spine formation. Science. 2019;364(6436):eaat8078. doi:10.1126/science. aat8078

32. Cunha AB, Frey BN, Andreazza AC, et al. Serum brain-derived neurotrophic factor is decreased in bipolar disorder during depressive and manic episodes. Neurosci Lett. 2006;8(398):215-219. doi:10.1016/j.neulet.2005.12.085

33. Machado-Vieira R, Dietrich MO, Leke R, et al. Decreased plasma brain derived neurotrophic factor levels in unmedicated bipolar patients during manic episode. BiolPsychiatry. 2007;61:142-144. doi:10.1016/j.biopsych.2006.03.070

34. Aan Het Rot M, Collins KA, Murrough JW, et al. Safety and efficacy of repeated-dose intravenous ketamine for treatment-resistant depression. Biol Psychiatry. 2010;15(67):139-145. doi:10.1016/j. biopsych.2009.08.038

35. Zhuo C, Ji F, Tian H, et al. Transient effects of multi-infusion ketamine augmentation on treatment-resistant depressive symptoms in patients with treatment-resistant bipolar depression - An open-label three-week pilot study. Brain Behav. 2020;10(8):e1674. doi: $10.1002 / b r b 3.1674$

36. Wilkinson ST, Ballard ED, Bloch MH, et al. The effect of a single dose of intravenous ketamine on suicidal ideation: a systematic review and individual participant data meta-analysis. $\mathrm{Am}$ $J \quad$ Psychiatry. 2018;175(2):150-158. doi:10.1176/appi. ajp.2017.17040472

37. Zhan Y, Zhang B, Zhou Y, et al. A preliminary study of anti-suicidal efficacy of repeated ketamine infusions in depression with suicidal ideation. J Affect Disord. 2019;15(251):205-212. doi:10.1016/j. jad.2019.03.071

38. Ballard ED, Ionescu DF, Vande Voort JL, et al. Improvement in suicidal ideation after ketamine infusion: relationship to reductions in depression and anxiety. J Psychiatr Res. 2014;58:161-166. doi:10.1016/j.jpsychires.2014.07.027

39. Murrough JW, Perez AM, Pillemer S, et al. Rapid and longer-term antidepressant effects of repeated ketamine infusions in treatment-resistant major depression. Biol Psychiatry. 2013;74:250-256.

40. Andrade C. Ketamine for depression, 5. Potential pharmacokinetic and pharmacodynamic drug interactions. J Clin Psychiatry. 2017;78 (7):e858-e861. doi:10.4088/JCP.17f11802 
41. Albott CS, Shiroma PR, Cullen KR, et al. The antidepressant effect of repeat dose intravenous ketamine is delayed by concurrent benzodiazepine use. J Clin Psychiatry. 2017;78(3):e308-e309. doi:10.4088/ JCP. 16111277

42. Andrashko V, Novak T, Brunovsky M, Klirova M, Sos P, Horacek J. The antidepressant effect of ketamine is dampened by concomitant benzodiazepine medication. Front Psychiatry. 2020;11:844. doi:10.3389/fpsyt.2020.00844

43. Anand A, Charney DS, Oren DA, et al. Attenuation of the neuropsychiatric effects of ketamine with lamotrigine: support for hyperglutamatergic effects of N-methyl-D-aspartate receptor antagonists. Arch Gen Psychiatry. 2000;57(3):270-276. doi:10.1001/archpsyc.57.3.270

44. Wilkowska A, Szałach K, Cubała WJ. Ketamine in bipolar disorder: a review. Neuropsychiatr Dis Treat. 2020;12(16):2707-2717. doi:10.2147/NDT.S282208

45. Jope RS. Anti-bipolar therapy: mechanism of action of lithium. Mol Psychiatry. 1999;4(2):117-128. doi:10.1038/sj.mp.4000494

46. Gastaldon C, Raschi E, Kane JM, Barbui C, Schoretsanitis G. PostMarketing safety concerns with esketamine: a disproportionality analysis of spontaneous reports submitted to the FDA adverse event reporting system. Psychother Psychosom. 2021;90(1):41-48. doi: $10.1159 / 000510703$
47. Rodrigues NB, McIntyre RS, Lipsitz O, et al. Safety and tolerability of IV ketamine in adults with major depressive or bipolar disorder: results from the Canadian rapid treatment center of excellence. Expert Opin Drug Saf. 2020;19(8):1031-1040. doi:10.1080/ 14740338.2020.1776699

48. Włodarczyk A, Cubała WJ. Safety and tolerability of ketamine use in treatment-resistant bipolar depression patients with regard to central nervous system symptomatology: literature review and analysis. Medicina (Kaunas). 2020;56(2):67. doi:10.3390/medicina56020067

49. Szarmach J, Cubała WJ, Włodarczyk A, Wiglusz MS. Short-term ketamine administration in treatment-resistant depression: focus on cardiovascular safety. Psychiatr Danub. 2019;31(Suppl 3):585-590.

50. Wilkowska A, Szałach K, Słupski J, et al. Affective switch associated with oral, low dose ketamine treatment in a patient with treatment resistant bipolar I depression. Case report and literature review. Front Psychiatry. 2020;3(11):516. doi:10.3389/fpsyt.2020.00516

\section{Publish your work in this journal}

Neuropsychiatric Disease and Treatment is an international, peerreviewed journal of clinical therapeutics and pharmacology focusing on concise rapid reporting of clinical or pre-clinical studies on a range of neuropsychiatric and neurological disorders. This journal is indexed on PubMed Central, the 'PsycINFO' database and CAS, and is the official journal of The International Neuropsychiatric Association (INA). The manuscript management system is completely online and includes a very quick and fair peer-review system, which is all easy to use. Visit http://www.dovepress.com/testimonials.php to read real quotes from published authors. 